Mineralogical Journal, Vol. 5, No. 5, Pp. 334-354, Sept., 1968

\title{
INFRARED DIFFRACTION AND THE \\ FAR INFRARED SPECTRA OF ANHYDROUS SULFATES
}

\author{
KEIICHI OMORI \\ Institute of Mineralogy, Petrology and Economic Geology, \\ Faculty of Science, Tohoku University, Sendai
}

\section{ABSTRACT}

A phenomenon analogous to X-ray diffraction and described as infrared diffraction has been obtained by mathematical analysis, between the absorption bands of the $\mathrm{SO}_{4}$ molecule in solution, and those of crystals of anglesite, barite, celestite, and anhydrite. The absorption bands of the fundamental vibrational mode are discussed for each mineral. From the results, it has been concluded that relationships showing wave motions exist between the bands of the spectrum. Infrared spectra are calculated by using the damped equation in the wave number region from 2000 to $100 \mathrm{~cm}^{-1}$. The features of the calculated spectra are similar to those of the spectrum obtained by using infrared spectrophotometers.

\section{Introduction}

Infrared spectra of anhydrous sulfates have been studied by Moenke (1962), Omori and Kerr (1963 and 1964), and Adler and Kerr (1965), while the absorption bands of barite have been discussed by Ramdes (1954) and Spencer (1959).

From these studies several characteristic features of the absorption bands have become better understood, but some fundamental properties remain to be explained. Frequencies of the fundamental vibrational modes of the $\mathrm{SO}_{4}$ molecule differ between those observed for crystal powders of sulfates and those observed in solution. The differences between these states have not yet been discussed. They can be interpreted clearly by the phenomenon designated infrared 
diffraction as given in this paper.

Also, far infrared spectra of anhydrous sulfates have not yet been studied, although recently, Angino has discussed the far infrared spectra of carbonates (1967) and referred to the spectra of plagioclase feldspars (1967a). Likewise, Omori (1968) has studied the far infrared spectrum of quartz, with a discussion of the relative wave motion, and compared the calculated spectrum with the observed spectrum in the region from 2000 to $100 \mathrm{~cm}^{-1}$. Similar relations have been found in the anhydrous sulfates. The calculated spectra are compared in the present paper. Thus, infrared spectra can be interpreted in terms of wave motion.

\section{Anhydrous sulfates used for the study}

Four anhydrous sulfates have been used for this study: anglesite $\left(\mathrm{PbSO}_{4}\right)$ from Los Lamentos, Chihuahua in Mexico, barite $\left(\mathrm{BaSO}_{4}\right)$ from Tazewell Co., Va., celestite $\left(\mathrm{SrSO}_{4}\right)$ from Strontian Island, Lake Erie, and anhydrite $\left(\mathrm{CaSO}_{4}\right)$ from Roundhouse, Nevada.

Each specimen was powdered in an agate mortar and a $\mathrm{KBr}$ disk was made by the usual method (Omori \& Kerr, 1964) for infrared study in the wave number region between 4000 and $400 \mathrm{~cm}^{-1}$. The polyethylene plate method was used for the far infrared study, where the plate was covered by nujol mixed with a small amount of sulfate powder (Omori, 1968). Infrared spectra were recorded by using three spectrophotometers. The Perkin-Elmer Type 125 with gratings was used for spectra in the region between 4000 and $400 \mathrm{~cm}^{-1}$ and the Hitachi Type EPI-ST with a $\mathrm{KBr}$ prism was used for the range between 900 and $400 \mathrm{~cm}^{-1}$. For the far infrared spectrum, the Hitachi Type FIS-1 with gratings was used between 500 and $60 \mathrm{~cm}^{-1}$.

The infrared spectra obtained are shown in Figs. 1 and 2, and the wave numbers of the absorption bands measured are given in Table 1. 


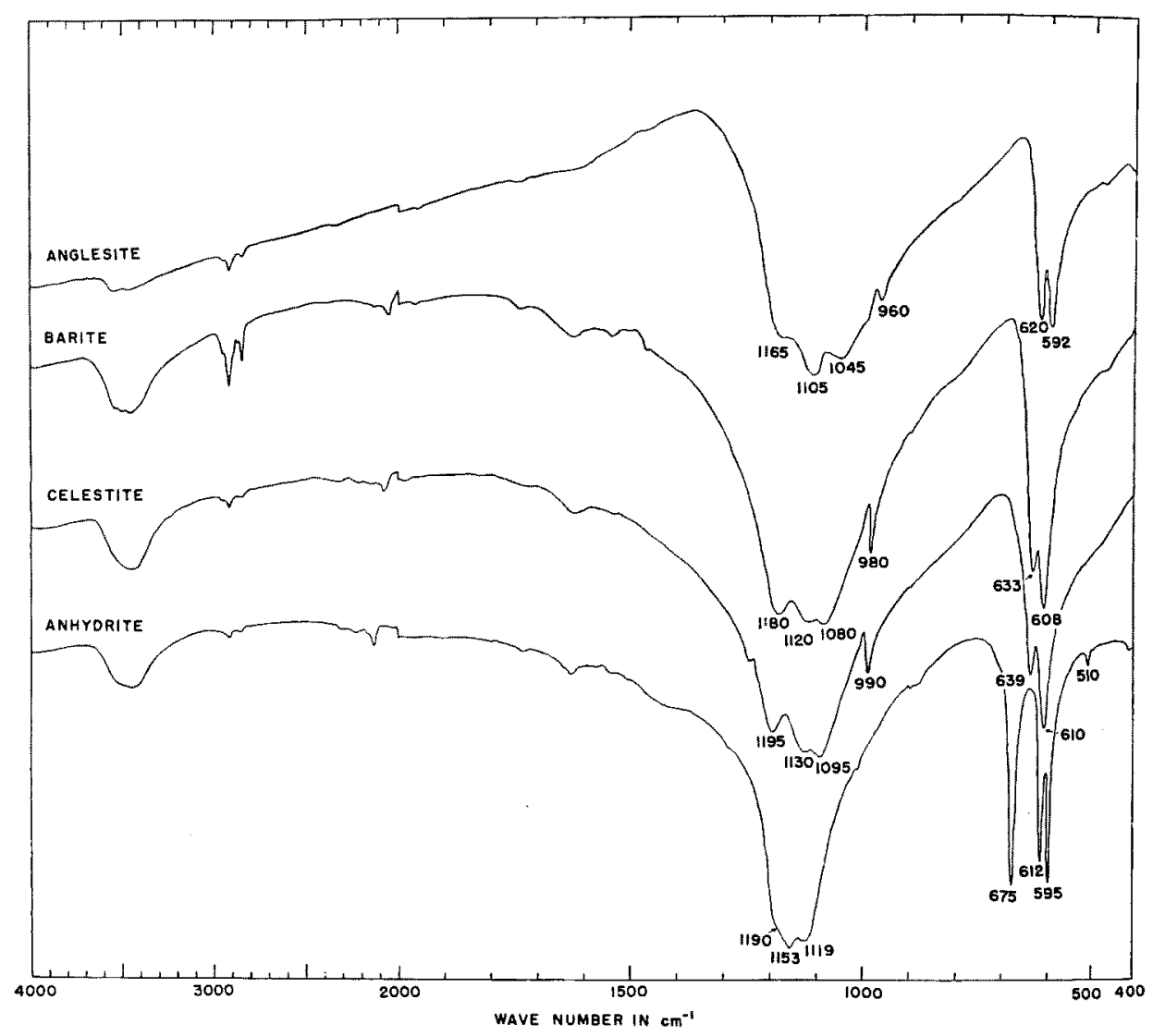

Fig. 1. Infrared spectra between 4000 and $400 \mathrm{~cm}^{-1}$ for anglesite, barite, celestite and anhydrite.

Four fundamental vibrational modes of the $\mathrm{SO}_{4}$ molecule

The fundamental vibrational modes of the $\mathrm{SO}_{4}$ molecule are known as four distinct internal modes, i.e. one nondegenerate mode $\nu_{1}\left(A_{3}\right)$, one doubly degenerate mode $\nu_{2}(E)$ and two triply degenerate modes $\nu_{3}\left(F_{2}\right)$ and $\nu_{4}\left(F_{2}\right)$ as shown in Fig. 3 after Mitra and Geilisse (1964).

The spectra for the minerals of the barite group have two strong bands $\nu_{3}$ and $\nu_{4}$, and one weak band $\nu_{1}$, while the spectrum of anhydrite shows two strong bands $\nu_{3}$ and $\nu_{4}$, and one weak band $\nu_{2}$. 

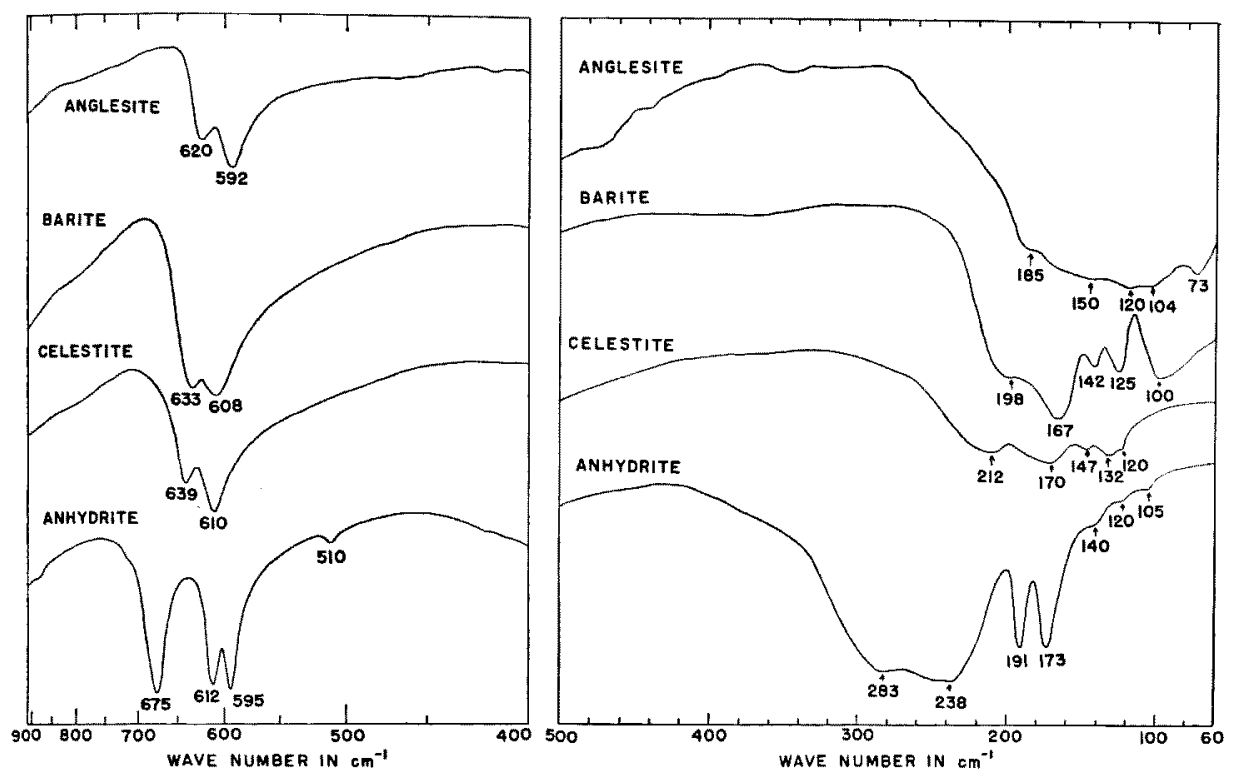

Fig. 2. Infrared spectra between 900 and $60 \mathrm{~cm}^{-1}$ for anglesite, barite, celestite and anhydrite

Differences in the band features between the spectra are caused by the crystal structure.

In the barite group, cations of $\mathrm{Pb}, \mathrm{Ba}$ or $\mathrm{Sr}$ are surrounded by twelve oxygen anions belonging to seven different $\mathrm{SO}_{4}$ molecules as shown in Fig. 4. While in anhydrite each cation of $\mathrm{Ca}$ is surrounded by eight oxygen anions of six different $\mathrm{SO}_{4}$ molecules.

Each mineral belongs to the orthorhombic holohedral class $2 / \mathrm{m}$ $2 / m 2 / m$, but the space group of the barite group is Pnma, while that of anhydrite is $B b m m$ with pseudotetragonal constants $b_{0}=6.96 \AA$ and $c_{0}=6.97 \AA$. As shown in Table 1 , cell constants become smaller as the cation radius decreases from anglesite to anhydrite.

The variation in the atomic weight of the cation causes the change in the wave numbers of the absorption bands, because the vibration of the atom is considered to be that of the nucleus. This will be discussed further in connection with the diffraction angles. 
Table 1. Comparative data for anhydrous sulfates of $\mathrm{Pb}, \mathrm{Ba}, \mathrm{Sr}$ and $\mathrm{Ca}$.

\begin{tabular}{|c|c|c|c|c|}
\hline Mineral & $\begin{array}{c}\text { Anglesite } \\
\mathrm{PbSO}_{4}\end{array}$ & $\begin{array}{l}\text { Barite } \\
\mathrm{BaSO}_{4}\end{array}$ & $\begin{array}{l}\text { Celestite } \\
\mathrm{SrSO}_{4}\end{array}$ & $\begin{array}{l}\text { Anhydrite } \\
\mathrm{CaSO}_{4}\end{array}$ \\
\hline Locality & $\begin{array}{c}\text { Los Lamentos } \\
\text { Chihuahua } \\
\text { Mexico }\end{array}$ & $\begin{array}{l}\text { Tazewell } \\
\text { Co., Va. }\end{array}$ & $\begin{array}{l}\text { Strontian } \\
\text { Island } \\
\text { Lake Erie }\end{array}$ & $\begin{array}{l}\text { Roundhouse } \\
\text { Nev. }\end{array}$ \\
\hline Absorption band & Meas. Calc. & Meas. Calc. & Meas. Calc. & Meas. \\
\hline \multirow{3}{*}{$\nu_{3}\left(1104 \mathrm{~cm}^{-1}\right)$} & $1165 \quad 1164.2$ & $1180 \quad 1183.2$ & $1195 \quad 1194.0$ & 1190 \\
\hline & 11051104.0 & $1120 \quad 1121.2$ & $1130 \quad 1128.1$ & 1153 \\
\hline & 10451043.8 & $1080 \quad 1077.6$ & $1095 \quad 1093.5$ & 1119 \\
\hline$\nu_{1}\left(981 \mathrm{~cm}^{-1}\right)$ & $960 \quad 958.0$ & $980 \quad 979.8$ & $990 \quad 989.6$ & - \\
\hline \multirow{3}{*}{$\nu_{4}\left(613 \mathrm{~cm}^{-1}\right)$} & $620 \quad 619.0$ & $633 \quad 635.4$ & $639 \quad 641.8$ & 675 \\
\hline & $592 \quad 592.0$ & $608 \quad 607.0$ & $610 \quad 611.1$ & 612 \\
\hline & - & - & - & 595 \\
\hline$\nu_{2}\left(451 \mathrm{~cm}^{-1}\right)$ & - & - & - & 510 \\
\hline \multirow{7}{*}{$\begin{array}{c}\text { Far infrared } \\
\text { bands }\end{array}$} & 185 & 198 & 212 & 283 \\
\hline & 150 & 167 & 170 & 238 \\
\hline & 120 & 142 & 147 & 191 \\
\hline & - & - & - & 173 \\
\hline & 104 & 125 & 132 & 140 \\
\hline & 73 & 100 & 120 & 120 \\
\hline & - & - & - & 105 \\
\hline Space Group & Pnma & Pnma & Pnma & $B b m m$ \\
\hline \multirow{3}{*}{$\begin{array}{l}\text { Unit cell } \\
\text { constants } \\
(\AA)\end{array}$} & 8.54 & 8.85 & 8.36 & 6.22 \\
\hline & 5.38 & 5.43 & 5.35 & 6.96 \\
\hline & 6.93 & 7.13 & 6.87 & 6.97 \\
\hline $\begin{array}{l}\text { Radius of } \\
\text { cation }(\AA)\end{array}$ & 1.20 & 1.35 & 1.13 & 0.99 \\
\hline $\begin{array}{l}\text { Atomic weight } \\
\text { of cation }\end{array}$ & 207.19 & 137.34 & 87.62 & 40.08 \\
\hline
\end{tabular}



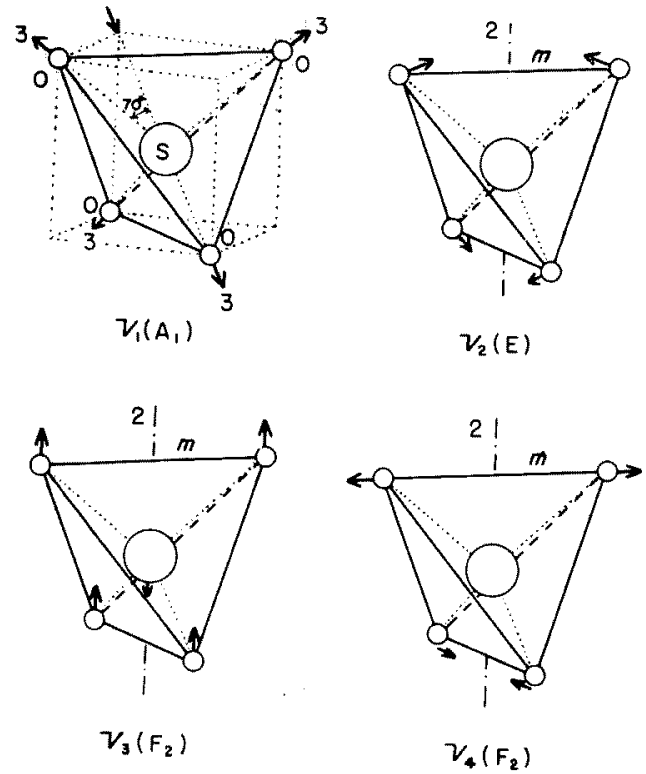

Fig. 3. Four distinct internal modes of the $\mathrm{SO}_{4}$ molecule (after Mitra and Geilisse, 1964).

\section{Infrared diffraction}

Every atom of the $\mathrm{SO}_{4}$ molecule in solution vibrates freely, but in the crystal, the atom vibrates under additional influences from the cations of $\mathrm{Pb}, \mathrm{Ba}, \mathrm{Sr}$ or $\mathrm{Ca}$. The differences between the two cause the variation in the wave number of the absorption band. The triply degenerate vibrational mode $\nu_{2}$ of the $\mathrm{SO}_{4}$ molecule in solution shows a unit wave number $1104 \mathrm{~cm}^{-1}$, while in celestite, for instance, it shows three different wave numbers 1195,1130 and $1095 \mathrm{~cm}^{-1}$ given in Table 1. Similar relations are found in other minerals and for other vibrational modes.

The relationships for the mode $\nu_{3}$ are shown schematically in Fig. 5, where the largest circle shows the relation between 1104 and $1195 \mathrm{~cm}^{-1}$, the middle circle found on the right side shows that between 1104 and $1130 \mathrm{~cm}^{-1}$, and the smallest circle on the right outer 

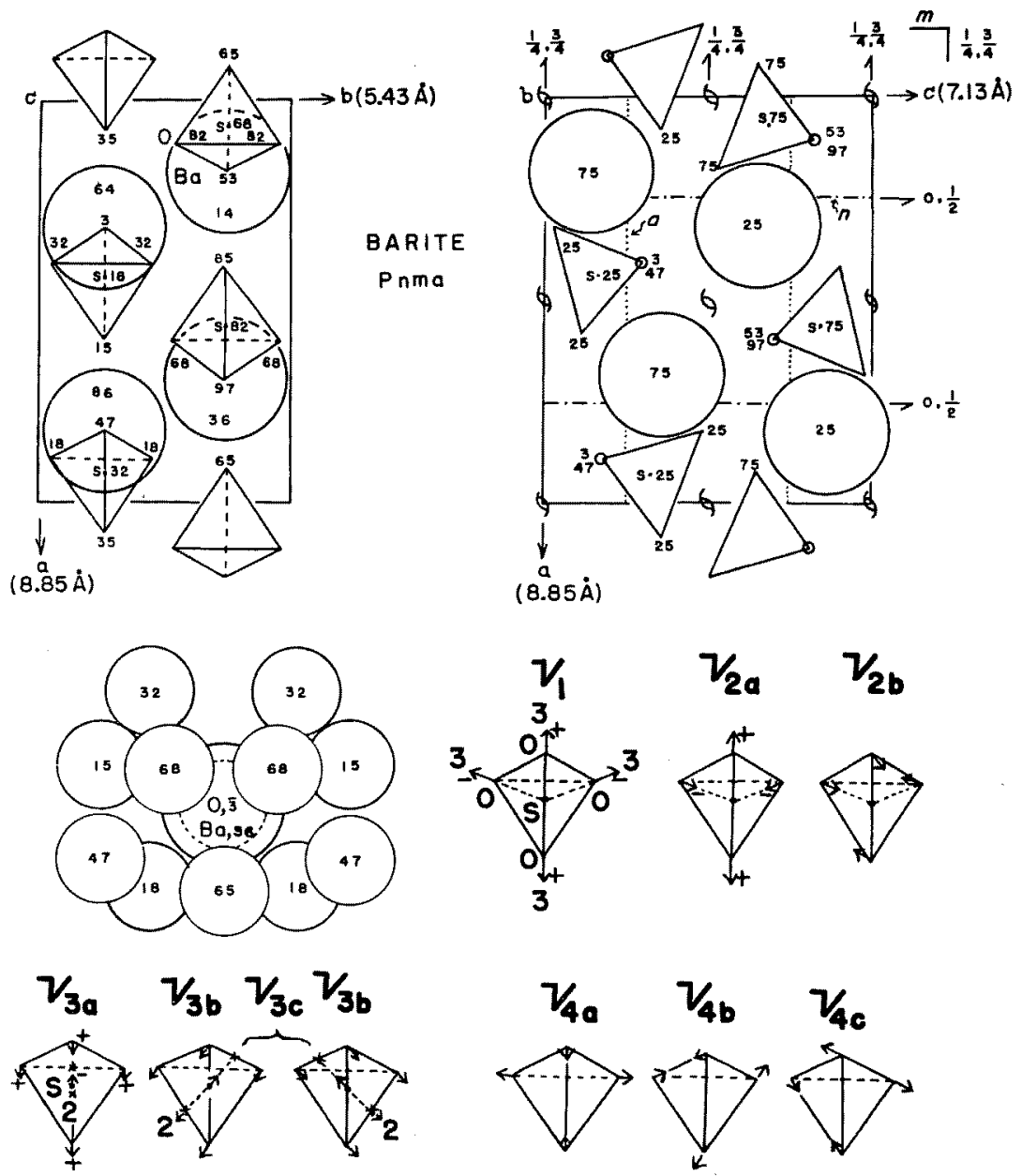

Fig. 4. Relationship between cations and anions in the barite group.

side shows that between 1104 and $1095 \mathrm{~cm}^{-1}$. The three heavy broken radii inclined at the center at $70^{\circ}$ show the relationship between 1195 , 1130 and $1095 \mathrm{~cm}^{-1}$.

Now, take points $\mathrm{A}, \mathrm{B}, \mathrm{H}$ and $\mathrm{C}$ at the wave numbers 1195,1130 , 1104 and $1095 \mathrm{~cm}^{-1}$ on the line respectively (Fig. 5). Consider the line from $\mathrm{O}_{0}$ to $\mathrm{H}$ as the beam of infrared radiation and also the largest circle as Ewald's sphere in X-ray diffraction. In the circle 

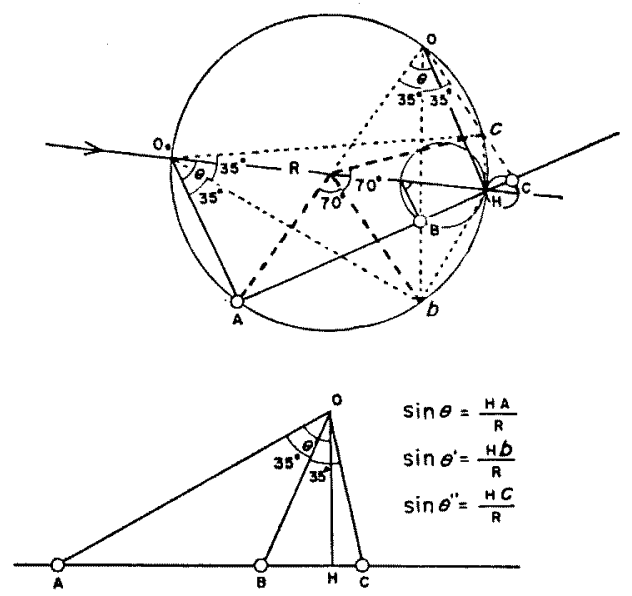

Fig. 5. Adaptation of Ewald's X-ray sphere to infrared.

we have

$$
\sin \theta=\mathrm{AH} / R,
$$

where $R$ is the diameter of the circle. Let $\mathrm{AH}=\delta$ and $r=$ the radius of the circle $(=R / 2)$, we then have

$$
\delta=2(r / n) \sin \theta,
$$

where $n$ is an integer. The equation is similar to the Bragg equation, $1 / d=2(1 / n \lambda) \sin \theta$.

Thus the relationship may be considered as infrared diffraction, and the infrared spectrum can be analysed in terms of wave motion.

Similar relationships are also found in the middle circle and in the smallest circle in Fig. 5.

Then, draw the line $\mathrm{OH}$ normal to the line $\mathrm{AC}$ at point $\mathrm{H}$ in Fig. 5. We have three equations,

$$
\begin{array}{ll} 
& \triangle \mathrm{O}_{0} \mathrm{AH} \equiv \triangle \mathrm{OHA}, \\
& \Delta \mathrm{O}_{0} b \mathrm{H} \backsim \triangle \mathrm{OHB}, \\
\text { and } & \Delta \mathrm{O}_{0} c \mathrm{H} \backsim \triangle \mathrm{OHC} .
\end{array}
$$

$\mathrm{BH}$ in the middle circle and $\mathrm{CH}$ in the smallest circle are equivalent 
to $b \mathrm{H}$ and $c \mathrm{H}$ in the largest circle respectively. Here, $\mathrm{AH}, b \mathrm{H}$ and $\mathrm{cH}$ in the largest circle show the relationships between the three fundamental vibrational modes $\nu_{3}$, represented by radii which incline at the center at $70^{\circ}$ to each other.

Then, we have

$$
\text { and } \begin{aligned}
\angle \mathrm{AO}_{0} \mathrm{H} & =\angle \mathrm{AOH}=\theta, \\
\angle b \mathrm{O}_{0} \mathrm{H} & =\angle \mathrm{BOH}=\theta-35^{\circ}, \\
\text { and } \quad & \angle c \mathrm{O}_{0} \mathrm{H}=\angle \mathrm{COH}=70^{\circ}-\theta,
\end{aligned}
$$

where the lines $\mathrm{O}_{0} b$ and $\mathrm{OB}$ are bisectrices of $\angle \mathrm{AO}_{0} c$ and $\angle \mathrm{AOC}$ respectively.

In the lower illustration of Fig. 5, which shows a part of the upper illustration, we have $\mathrm{OA}=2 r=R$ and $\sin \theta=\mathrm{HA} / R, \angle \mathrm{AOH}=\theta$, $\angle \mathrm{AOB}=35^{\circ}$ and $\angle \mathrm{BOC}=35^{\circ}$.

Plot $\mathrm{A}, \mathrm{B}, \mathrm{H}$ and $\mathrm{C}$ on a line using the wave numbers shown in Table 2, and draw a normal at $\mathrm{H}$ to the line AC. Then, plot the three lines $\mathrm{OA}, \mathrm{OB}$ and $\mathrm{OC}$ as shown in Fig. 5, keeping the following angles constant,

$$
\angle \mathrm{AOB}=\angle \mathrm{BOC}=35^{\circ} .
$$

Analyses for the fundamental vibrational modes of anglesite, barite and celestite are shown in Fig. 6, where the diameter of the circle $R=2 r=\mathrm{OA}=105 \mathrm{~cm}^{-1}$.

When $\mathrm{HA}=\nu_{3 a}, \mathrm{HB}=\nu_{3 b}$ and $\mathrm{HC}=\nu_{3 c}$ for anglesite, barite and celestite, we have the following equations from the lower illustration in Fig. 5.

$$
\text { and } \quad \begin{aligned}
\nu_{3 a} & =1104 \mathrm{~cm}^{-1}+R \sin \theta, \\
\nu_{3 b} & =1104 \mathrm{~cm}^{-1}+R \cos \theta \cdot \tan \left(\theta-35^{\circ}\right), \\
\nu_{3 c} & =1104 \mathrm{~cm}^{-1}-R \cos \theta \cdot \tan \left(70^{\circ}-\theta\right) .
\end{aligned}
$$

Next, we have the following equations for $\nu_{1}, \nu_{4 a}$ and $\nu_{4 b}$ from Fig. 6 .

$$
\text { and } \quad \begin{aligned}
& \nu_{1}=981 \mathrm{~cm}^{-1}-R \cos \theta \cdot \tan \left(50^{\circ}-\theta\right), \\
& \nu_{4 a}=613 \mathrm{~cm}^{-1}+R \cos \theta \cdot \tan \left(\theta-31^{\circ}\right), \\
& \nu_{4 b}=1.5 \nu_{4 a}-0.5 R \cdot \sin \theta-0.5 \times 613 \mathrm{~cm}^{-1} .
\end{aligned}
$$


$v_{3}$

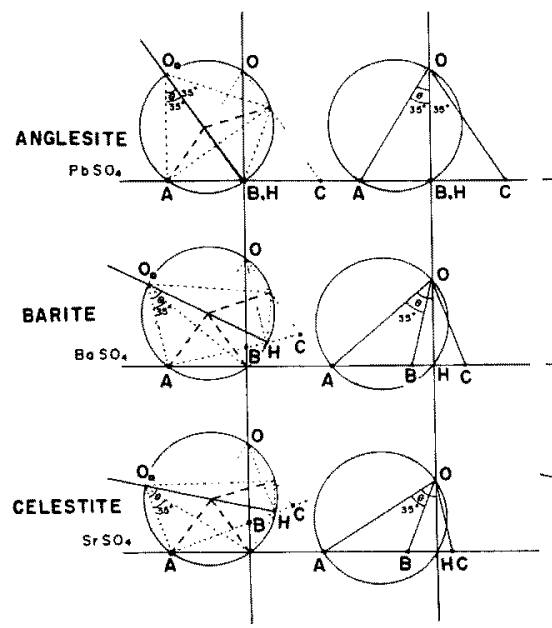

$\nu_{1}$

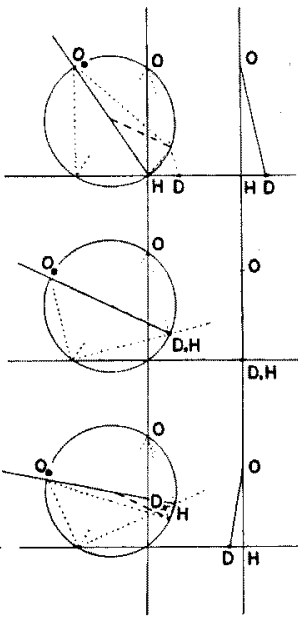

$v_{4}$

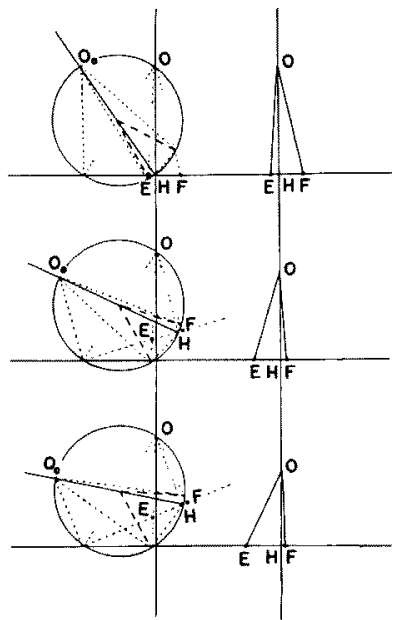

Fig. 6. Analyses for the fundamental vibrational modes of anglesite, barite and celestite.

Table 2. Diffraction angles for anglesite, barite, and celestite.

\begin{tabular}{l|c|c|c|c}
\hline \multirow{2}{*}{ Mineral } & $\begin{array}{c}\text { Chemical } \\
\text { formula }\end{array}$ & $\begin{array}{c}\text { Atomic } \\
\text { weight } \\
\text { of cation }\end{array}$ & \multicolumn{2}{|c}{ Diffraction angle for $\nu_{3 a}$} \\
\cline { 5 - 5 } & $\mathrm{PbSO}_{4}$ & 207.19 & $35^{\circ}$ & $35.15^{\circ}$ \\
\hline Anglesite & $\mathrm{BaSO}_{4}$ & 137.34 & 49 & 49.12 \\
Barite & $\mathrm{SrSO}_{4}$ & 87.62 & 59 & 59.07 \\
\hline
\end{tabular}

Then, take $R=105 \mathrm{~cm}^{-1}$ and take $\theta$ as the angle shown in Table 2 . The wave numbers of the fundamental mode for each mineral may be calculated as shown in Table 1 . The measured wave numbers agree well with the calculated numbers.

\section{Diffraction angles}

The diffraction angles $\theta$ for $\nu_{3 a}$ were measured for anglesite, barite and celestite as shown in Fig. 6. The angles were then plotted on the line $\theta, \nu_{3 a}$ versus the atomic weights of $\mathrm{Pb}, \mathrm{Ba}$ and $\mathrm{Sr}$ shown 


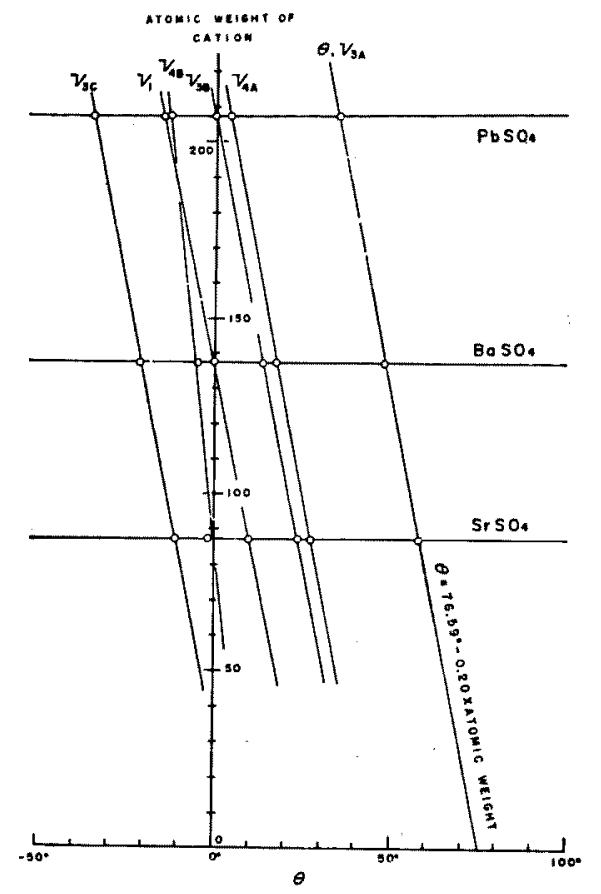

Fig. 7. Lattice lines derived from angles of the infrared diffraction.

in Fig. 7, which yields the equation, $\theta=76.59^{\circ}-0.20 \times($ atomic weight of the cation $(\mathrm{Pb}, \mathrm{Ba}$ or $\mathrm{Sr}))$.

The diffraction angles calculated from the equation are shown in Table 2.

Straight lines derived from the angles are parallel to the line of $\nu_{3 a}$ in Fig. 7 except one line, $\nu_{4 b}$. The relationships between $\nu_{3 a}, \nu_{b b}$, $\nu_{a c}, \nu_{1}, \nu_{4 a}$ and $\nu_{4 b}$ for the minerals of barite group are shown in Fig. 8. Similar relations also appear in Fig. 6.

In Fig. 8, the line with the points for $\nu_{4 b}$, for $\mathrm{PbSO}_{4}, \mathrm{BaSO}_{4}$ and $\mathrm{SrSO}_{4}$ is parallel to that for $\nu_{4 a}$, while the other lines converge at one point. This shows that the vibrational relationship of $\nu_{4 b}$ is not similar to other modes. 


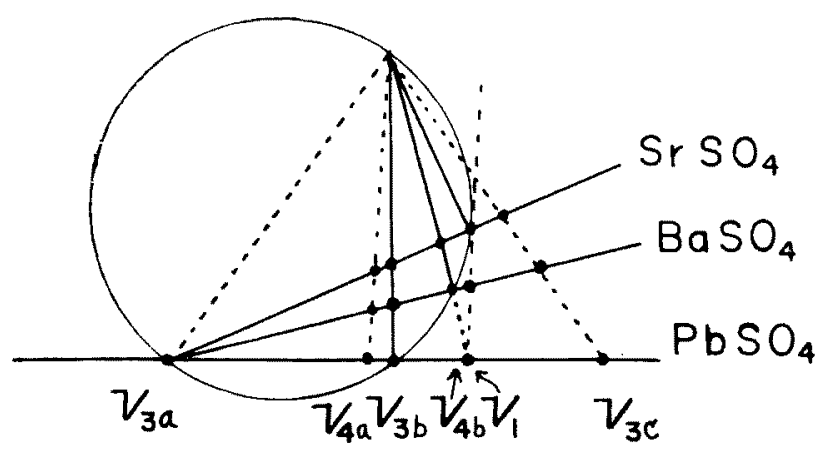

Fig. 8. Positions of lattice lines for $\mathrm{Sr}, \mathrm{Ba}$ and $\mathrm{Pb}$ sulfates.

Far infrared spectra of anhydrous sulfates

Far infrared absorption spectra of anglesite, barite, celestite and anhydrite are shown in Fig. 2, while the wave numbers of the absorption bands are shown in Table 1 . The wave numbers of anhydrite show no similarity to those of the minerals of the barite group.

For anhydrite, the band at $1190 \mathrm{~cm}^{-1}$ in the infrared region is considered to be a double wave number band $2 \times 595 \mathrm{~cm}^{-1}$ for $\nu_{4}$. The fundamental vibrational mode $\nu_{2}$ is found at $510 \mathrm{~cm}^{-1}$ and three bands of the mode $\nu_{4}$ are found at 675,612 and $595 \mathrm{~cm}^{-1}$.

These characteristic features of anhydrite are repeated in the far infrared region. Two bands at 285 and $238 \mathrm{~cm}^{-1}$ are considered to be a repetition of $\nu_{3}$ bands at 1153 and $1119 \mathrm{~cm}^{-1}$ respectively, because the differences between them are almost the same, 283-238 $=45 \mathrm{~cm}^{-1}$ and $1153-1119=34 \mathrm{~cm}^{-1}$.

Three bands at 238, 191 and $173 \mathrm{~cm}^{-1}$ are also the repeated bands of $\nu_{4}$ at 675,612 and $595 \mathrm{~cm}^{-1}$ and one band $173 \mathrm{~cm}^{-1}$ is that of $\nu_{2}$ at $510 \mathrm{~cm}^{-1}$.

Three other bands of anhydrite at 140,120 and $105 \mathrm{~cm}^{-1}$ are considered to be the half wave number bands for 283,238 and $191 \mathrm{~cm}^{-1}$ respectively.

For the minerals of the barite group, similar repetition occurs, 
but more simply between the bands of the infrared and the far infrared region. For anglesite, for instance, three bands at 185, 120 and $73 \mathrm{~cm}^{-1}$ represent $\nu_{3}$ at 1165,1105 and $1045 \mathrm{~cm}^{-1}$, respectively, one band at $104 \mathrm{~cm}^{-1}$ is that of $\nu_{1}$ at $960 \mathrm{~cm}^{-1}$, and two bands at 120 and $104 \mathrm{~cm}^{-1}$ are those of $\nu_{4}$ at 620 and $592 \mathrm{~cm}^{-1}$ respectively.

Barite and celestite show similar features.

Damped vibrational equation for two bands between the infrared region and the far infrared region

The vibrational relationship of a damped curve is considered to exist between the vibration of two bands in the infrared and in the far infrared region.

The general equation of the damped vibrational curve may be shown as $y=\cos a x / e^{b x}$, where $y$ is the frequency. If one assumes constants $a=1$ and $b=1$, the equation is written as $y=\cos x / e^{x}$. When $y$ is the amplitude of the wave motion, the intensity is shown as $y^{2}=\left(\cos x / e^{x}\right)^{2}$. The calculated values of $y^{2}$ are shown for each degree of $x$ in Table 3 , where $y^{2}$ is very small between $x=242^{\circ}$ and $300^{\circ}$. The damped curve for $y$ and the intensity curve $y^{2}$ are shown in Fig. 9.

When $A$ is the amplitude for the infrared wave motion, we have

$$
A=\frac{\cos \left(\frac{\nu_{0} \sim \nu_{x}}{\nu_{0}-\nu_{3 / 4} \cdot \pi} \times 135^{\circ}\right)}{e^{\left(\frac{\nu_{0} \sim \nu_{x}}{\nu_{0}-\nu_{3 / 4} \cdot \pi} \times \frac{3}{4} \pi\right)}},
$$

where $\nu_{0}$ is the wave number of the absorption bands $\nu_{3}, \nu_{4}, \nu_{1}$ and $\nu_{2}, \nu_{3 / 4 \cdot \pi}$ is that of each infrared band, and $\nu_{x}$ is that to be calculated. Intensity $I$, or the transmittance, of the spectrum is calculated as the sum of each $A^{2}$, namely

$$
I=\Sigma A_{i}^{2} .
$$


Table 3. Calculated values of $y^{2}$ for each degree of $x$.

\begin{tabular}{|c|c|c|c|c|c|c|c|c|c|c|c|}
\hline$y^{2}$ & $0^{\circ}$ & $1^{\circ}$ & $2^{\circ}$ & $3^{\circ}$ & $4^{\circ}$ & $5^{\circ}$ & $6^{\circ}$ & $7^{\circ}$ & $8^{\circ}$ & $9^{\circ}$ & $10^{\circ}$ \\
\hline $\begin{array}{l}0 \\
1 \\
2 \\
3 \\
4\end{array}$ & $\begin{array}{r}1.0000 \\
.6841 \\
.4393 \\
.2632 \\
.1453\end{array}$ & $\begin{array}{l}.9654 \\
.6564 \\
.4187 \\
.2490 \\
.1361\end{array}$ & $\begin{array}{l}.9314 \\
.6293 \\
.3989 \\
.2354 \\
.1274\end{array}$ & $\begin{array}{l}.8981 \\
.6031 \\
.3796 \\
.2223 \\
.1192\end{array}$ & $\begin{array}{l}.8654 \\
.5775 \\
.3611 \\
.2098 \\
.1114\end{array}$ & $\begin{array}{l}8335 \\
.5527 \\
.3432 \\
.1978 \\
.1039\end{array}$ & $\begin{array}{l}8021 \\
5286 \\
3260 \\
1863 \\
.0969\end{array}$ & $\begin{array}{l}.7716 \\
.5052 \\
.3093 \\
.1753 \\
.0902\end{array}$ & $\begin{array}{l}.7417 \\
.4825 \\
.2934 \\
.1648 \\
.0838\end{array}$ & $\begin{array}{l}.7125 \\
.4606 \\
.2780 \\
.1548 \\
.0778\end{array}$ & $\begin{array}{l}.6841 \\
.4393 \\
.2632 \\
.1453 \\
.0721\end{array}$ \\
\hline $\begin{array}{l}5 \\
6 \\
7 \\
8 \\
9\end{array}$ & $\begin{array}{l}.0721 \\
.0308 \\
.0102 \\
.0018 \\
.0000\end{array}$ & $\begin{array}{l}.0668 \\
.0280 \\
.0089 \\
.0014 \\
.0000\end{array}$ & $\begin{array}{l}.0617 \\
.0253 \\
.0077 \\
.0011 \\
.0000\end{array}$ & $\begin{array}{l}.0569 \\
.0229 \\
.0067 \\
.0008 \\
.0001\end{array}$ & $\begin{array}{l}0525 \\
0206 \\
0057 \\
0006 \\
0002\end{array}$ & $\begin{array}{l}.0482 \\
.0185 \\
.0049 \\
.0004 \\
.0003\end{array}$ & $\begin{array}{l}.0443 \\
.0165 \\
.0041 \\
.0002 \\
.0004\end{array}$ & $\begin{array}{l}.0406 \\
.0147 \\
.0034 \\
.0001 \\
.0005\end{array}$ & $\begin{array}{l}.0371 \\
.0131 \\
.0028 \\
.0001 \\
.0006\end{array}$ & & $\begin{array}{l}.0308 \\
.0102 \\
.0018 \\
.0000 \\
.0009\end{array}$ \\
\hline $\begin{array}{l}10 \\
11 \\
12 \\
13 \\
14\end{array}$ & $\begin{array}{l}.0009 \\
.0025 \\
.0038 \\
.0044 \\
.0044\end{array}$ & $\begin{array}{l}.0011 \\
.0027 \\
.0039 \\
.0044 \\
.0044\end{array}$ & $\begin{array}{l}.0012 \\
.0028 \\
.0040 \\
.0045 \\
.0044\end{array}$ & $\begin{array}{l}0014 \\
.0030 \\
.0041 \\
.0045 \\
.0043\end{array}$ & $\begin{array}{l}.0016 \\
.0031 \\
.0041 \\
.0045 \\
.0043\end{array}$ & $\begin{array}{l}.0017 \\
.0032 \\
.0042 \\
.0045 \\
.0043\end{array}$ & $\begin{array}{l}.0019 \\
.0034 \\
.0042 \\
.0045 \\
.0042\end{array}$ & $\begin{array}{l}.0020 \\
.0035 \\
.0043 \\
.0045 \\
.0042\end{array}$ & $\begin{array}{l}.0022 \\
.0036 \\
.0043 \\
.0045 \\
.0041\end{array}$ & $\begin{array}{r}.0024 \\
0037 \\
.0044 \\
.0044 \\
.0040\end{array}$ & $\begin{array}{l}.0025 \\
.0038 \\
.0044 \\
.0044 \\
.0040\end{array}$ \\
\hline $\begin{array}{l}15 \\
16 \\
17 \\
18 \\
19\end{array}$ & $\begin{array}{l}.0040 \\
.0033 \\
.0026 \\
.0019 \\
.0013\end{array}$ & $\begin{array}{l}.0039 \\
.0032 \\
.0025 \\
.0018 \\
.0012\end{array}$ & $\begin{array}{l}.0039 \\
.0032 \\
.0024 \\
.0017 \\
.0012\end{array}$ & $\begin{array}{l}.0038 \\
.0031 \\
.0023 \\
.0017 \\
.0011\end{array}$ & $\begin{array}{l}.0037 \\
.0030 \\
.0023 \\
.0016 \\
.0011\end{array}$ & & $\begin{array}{l}.0036 \\
.0029 \\
.0021 \\
.0015 \\
.0010\end{array}$ & $\begin{array}{l}.0035 \\
.0028 \\
.0021 \\
.0014 \\
.0009\end{array}$ & $\begin{array}{l}.0035 \\
.0027 \\
.0020 \\
.0014 \\
.0009\end{array}$ & & $\begin{array}{l}.0033 \\
.0026 \\
.0019 \\
.0013 \\
.0008\end{array}$ \\
\hline $\begin{array}{l}20 \\
21 \\
22 \\
23 \\
24\end{array}$ & $\begin{array}{l}.0008 \\
.0005 \\
.0003 \\
.0001 \\
.0001\end{array}$ & $\begin{array}{l}.0008 \\
.0005 \\
.0003 \\
.0001 \\
.0001\end{array}$ & $\begin{array}{l}.0007 \\
.0004 \\
.0002 \\
.0001 \\
.0000\end{array}$ & $\begin{array}{l}.0007 \\
.0004 \\
.0002 \\
.0001 \\
.0000\end{array}$ & $\begin{array}{l}.0007 \\
.0004 \\
.0002 \\
.0001 \\
.0000\end{array}$ & $\begin{array}{l}.0006 \\
.0004 \\
.0002 \\
.0001 \\
.0000\end{array}$ & $\begin{array}{l}.0006 \\
.0003 \\
.0002 \\
.0001 \\
.0000\end{array}$ & $\begin{array}{l}.0006 \\
.0003 \\
.0002 \\
.0001 \\
.0000\end{array}$ & $\begin{array}{l}.0005 \\
.0003 \\
.0002 \\
.0001 \\
.0000\end{array}$ & $\begin{array}{l}.0005 \\
.0003 \\
.0001 \\
.0001 \\
.0000\end{array}$ & $\begin{array}{l}.0005 \\
.0003 \\
.0001 \\
.0001 \\
.0000\end{array}$ \\
\hline $\begin{array}{l}25 \\
26 \\
27 \\
28 \\
29\end{array}$ & $\begin{array}{l}.0000 \\
.0000 \\
.0000 \\
.0000 \\
.0000\end{array}$ & $\begin{array}{l}.0000 \\
.0000 \\
.0000 \\
.0000 \\
.0000\end{array}$ & $\begin{array}{l}.0000 \\
.0000 \\
.0000 \\
.0000 \\
.0000\end{array}$ & $\begin{array}{l}.0000 \\
.0000 \\
.0000 \\
.0000 \\
.0000\end{array}$ & $\begin{array}{l}.0000 \\
.0000 \\
.0000 \\
.0000 \\
.0000\end{array}$ & $\begin{array}{l}.0000 \\
.0000 \\
.0000 \\
.0000 \\
.0000\end{array}$ & $\begin{array}{l}.0000 \\
.0000 \\
.0000 \\
.0000 \\
.0000\end{array}$ & $\begin{array}{l}.0000 \\
.0000 \\
.0000 \\
.0000 \\
.0000\end{array}$ & $\begin{array}{l}.0000 \\
.0000 \\
.0000 \\
.0000 \\
.0000\end{array}$ & $\begin{array}{l}.0000 \\
.0000 \\
.0000 \\
.0000 \\
.0000\end{array}$ & $\begin{array}{l}.0000 \\
.0000 \\
.0000 \\
.0000 \\
.0000\end{array}$ \\
\hline
\end{tabular}

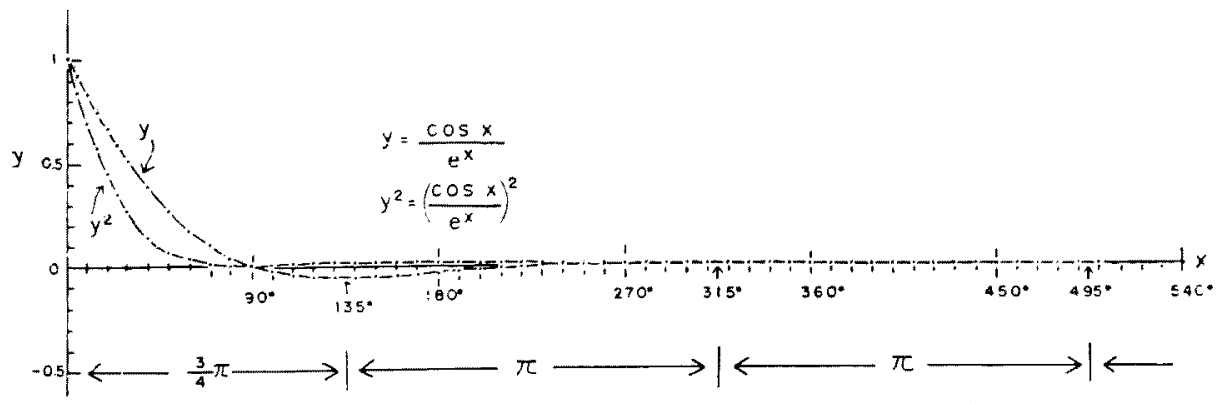

Fig. 9. Damped curves for $y$ and intensity curve for $y^{2}$. 


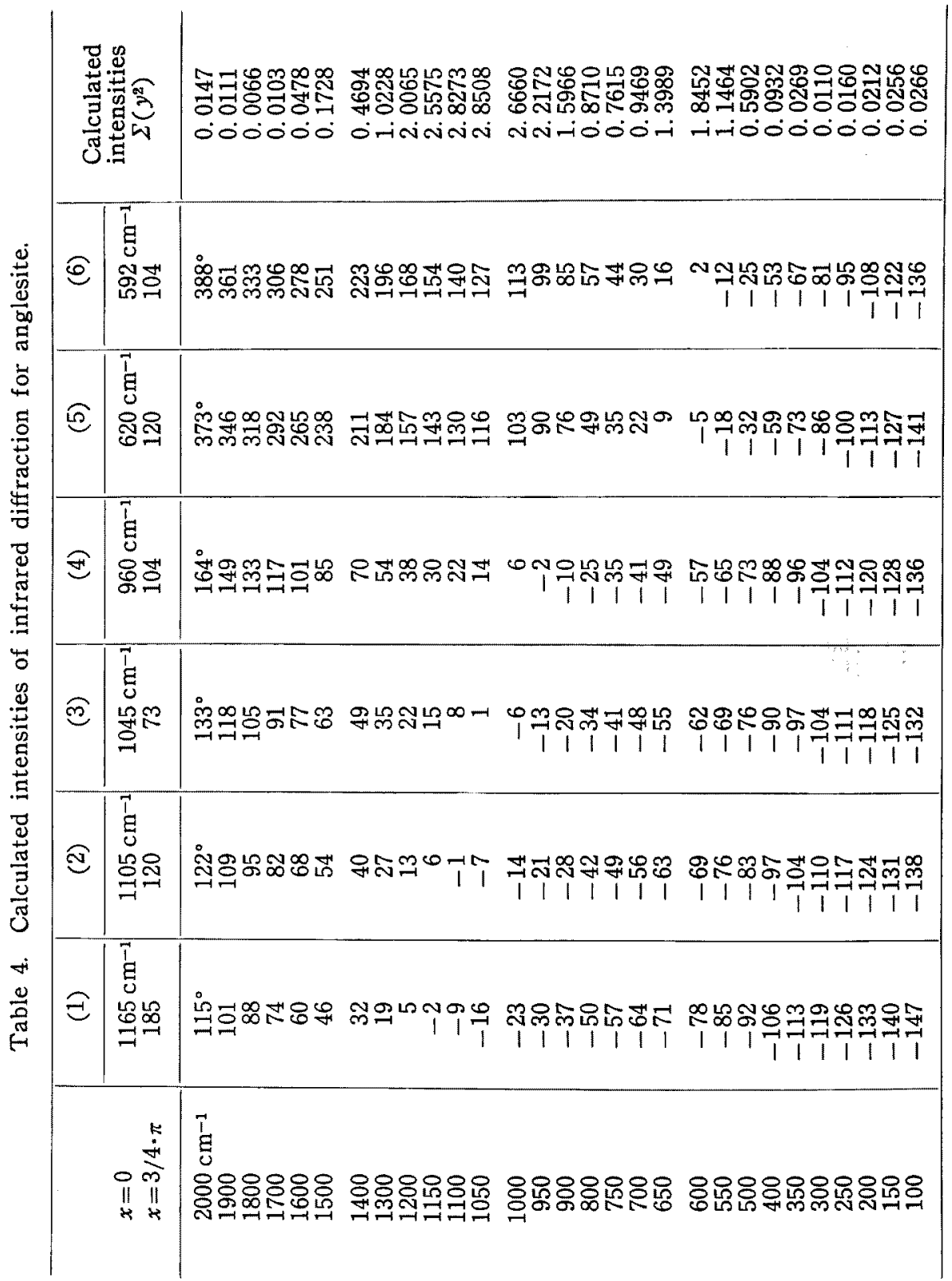




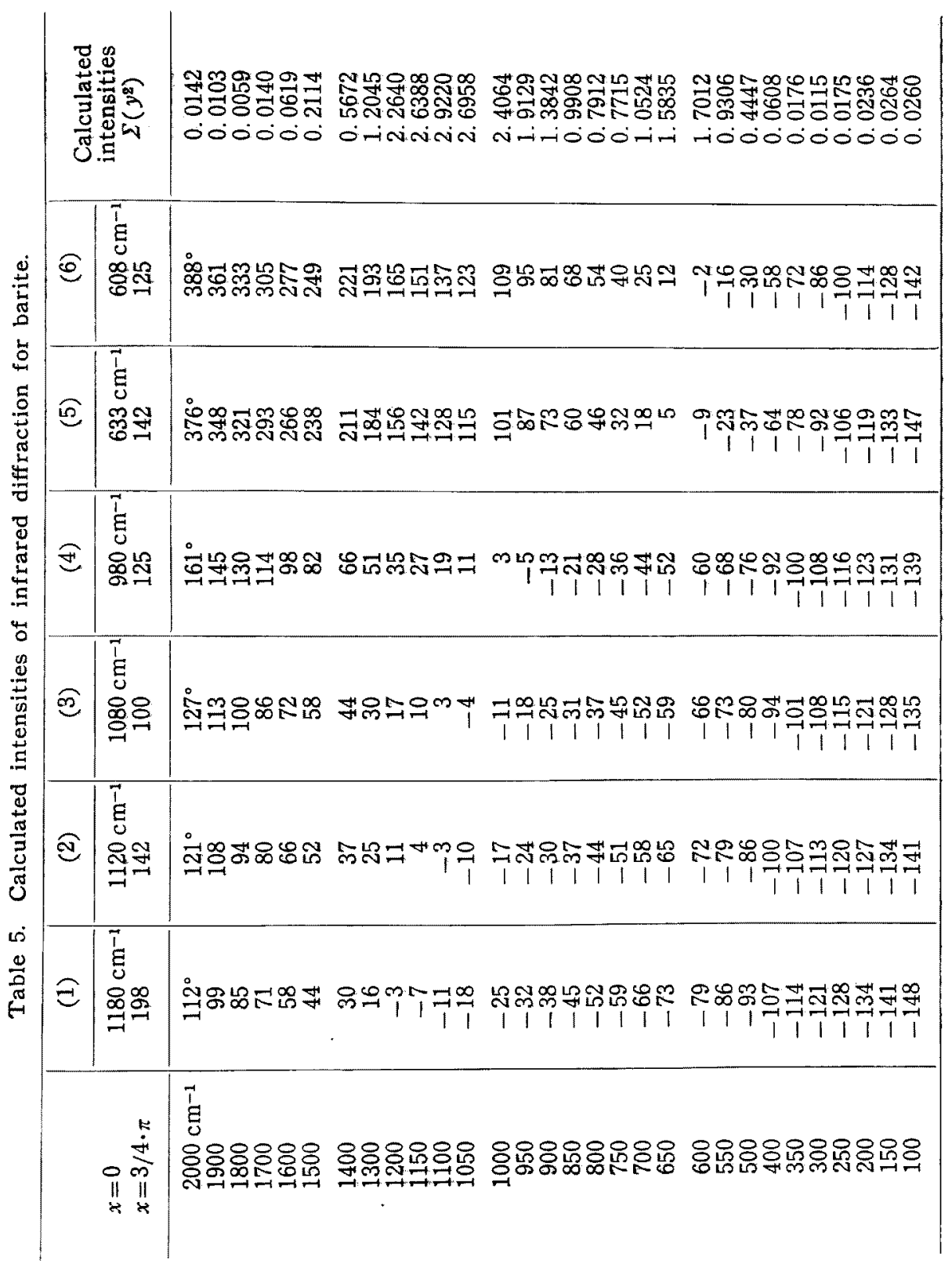




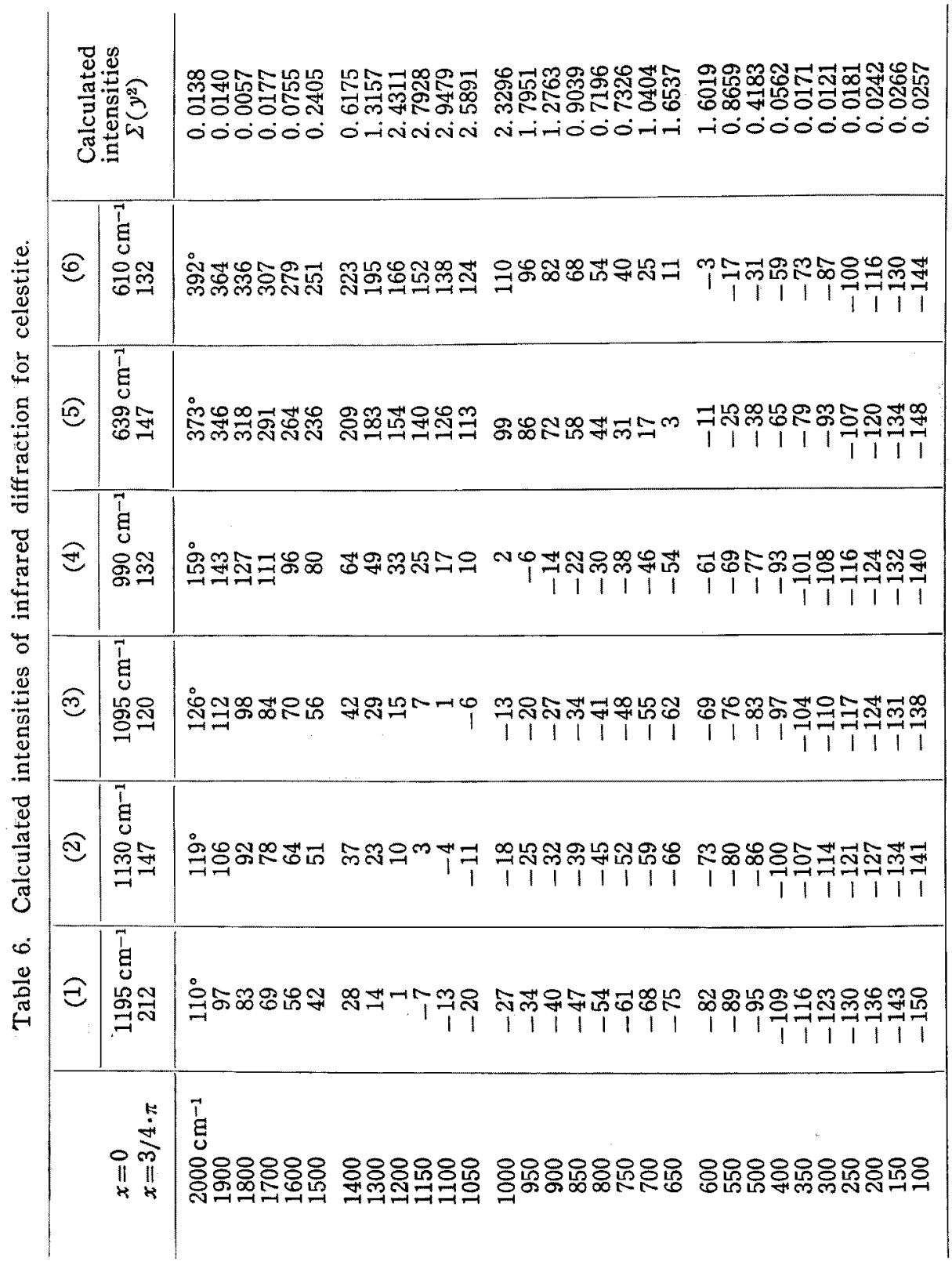









\section{Calculated spectra and observed spectra}

The intensities of the whole region of spectra can be calculated from the equation $\Sigma A_{i}^{2}$. The calculated results for the wave number region $2000 \mathrm{~cm}^{-1}$ to $100 \mathrm{~cm}^{-1}$ are shown for anglesite (Table 4), barite (Table 5), celestite (Table 6) and anhydrite (Table 7).

Spectra illustrating the curves derived are shown in Fig. 10. These spectra correspond similarly in general to the observed spectra shown in Figs. 1 and 2.

\section{WAVE NUMBER IN $\mathrm{cm}^{-1}$}

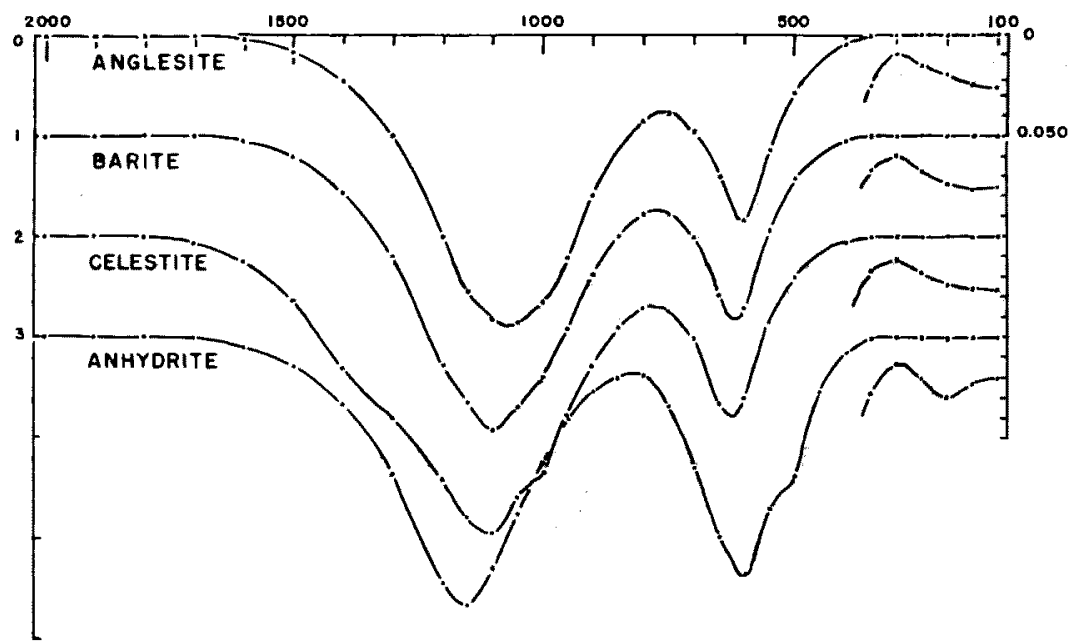

Fig. 10. Calculated spectra for anglesite, barite, celestite and anhydrite.

The method is useful for the interpretation of infrared spectra by using the damped equation of the wave motion. It shows that an intimate relationship exists between the bands of the infrared region and the far infrared region, i.e. between the inner molecular vibrations and the outer lattice vibrations. 
Conclusions

Infrared absorption bands of anglesite, barite, celestite and anhydrite are shown in the infrared and the far infrared regions. The relationship described as infrared diffraction has been developed, which is similar in many respects to $\mathrm{X}$-ray diffraction.

A relationship is shown by the equation $\delta=2(r / n) \sin \theta$, where the diffraction angle $\theta$ is inversely proportional to the atomic weights of cations $\mathrm{Pb}, \mathrm{Ba}, \mathrm{Sr}$ or $\mathrm{Ca}$.

It is shown that a wave motion relationship exists between bands in the infrared and the far infrared regions. The relationship can be shown by the equation of the damped vibration. The spectra of anglesite, barite, celestite and anhydrite have been calculated from this equation, and show features similar to those recorded by the infrared spectrophotometers.

The author is grateful for the help in conducting the far infrared study by Professor Susumu Kinumaki of the Chemical Research Institute of Non-Aqueous Solutions, Tohoku University, and for critical reading of the manuscript by Professor Tadanobu Kojima of the Institute of Physics, Tohoku University, and also for encouragement in the study and a critical review of the manuscript by Newberry Professor Em. Paul F. Kerr of Columbia University.

Likewise, it is a pleasure to acknowledge an aid from the Research Fund for Sciences of the Ministry of Education of Japan.

\section{REFERENCES}

Adler, H.H. \& KeRR, P.F. (1965). Amer, Min., 50, 132.

Angino, E.E. (1967). Amer. Min., 52, 137.

ANGINo, E. E. (1967a). Relation between chemical composition and far infrared spectra of plagioclase feldspars. Progm. 1967, Ann. Meet., 7.

Mitra, S. S. \& Gielisse, P. J. (1964). Infrared spectra of crystals: Progress in Infrared Spectroscopy edited by H. A. Szymansky. Plenum Press, N.Y., 
2, 47-125.

Moenke, H. (1962). Spektralanalyse von Mineralien und Gesteinen. Akaa Verlag., Leipzig, 127-135.

OMORI, K. (1968). J. Miner. Soc. Japan, 9, 15 (in Japanese).

OMORI, K. \& KerR, P.F. (1963). Geol. Soc. Amer. Bull., 74, 709.

OMORI, K. \& KerR, P.F. (1964). Sci. Repts. Tohoku Univ., ser. 3, 9, 1.

Ramdes, A. K. (1954). Proc. Ind. Acad. Sci. (A), 39, 81.

SPENCER, B. (1959). Biochem. Jour., 73, 442.

Manuscript received 22 May 1968. 